\title{
Coffee Houses Culture in Erbil: A Review
}

\author{
Asst. Lec. Herdn Ibrahim Ahmed \\ Salahaddin University, Erbil \\ E-mail: herdnahmad@gmail.com
}

\section{INFO}

\section{Article History:}

Received: 25/10/2018

Accepted: 27/11/2018

Published: Winter 2018

Doi:

10.25212/Ifu.qzj.3.4.33

\section{Keywords:}

\section{coffeehouse}

people, significant

place, human progress, changing information, political, cultural, social, economic

\section{ABSTRACT}

Coffee has been known to the world since the 12th century, and it has begun to serve a drink in a special place known as coffeehouse since the 14th century. At first, it was only for drinking coffee, then it has become a place for chatting and sharing problems with other people. Coffee shops are regarded as a significant place from the 16th century until now. Coffee shops are serving under different names in Erbi, but the coffee shops are the modern name. Furthermore, they have significant effects on the human progress, by performing many functions such as changing information, news. To sum up, coffee shops provide an opportunity for people to discuss political, cultural, social and economic subjects.

\section{INTRODUCTION}

At the beginning, Coffeehouse's role was such an informal educational institution where different functions were performed. For instance, people learned patterns of behaviour, respect and love in a relationship and manners of chatting. Those learnings often were taking place spontaneously. 


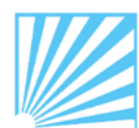

LF U
QALAAI ZANIST SCIENTIFIC JOURNAL

A Scientific Quarterly Refereed Journal Issued by Lebanese French University - Erbil, Kurdistan, Iraq

Vol. ( 3 ), Issue ( 4 ), Fall 2018

ISSN 2518-6566 (Online) - ISSN 2518-6558 (Print)

Then, having fun became the major activities in these places. In fact, the situation which is formulated in the form of "to enjoy" covers chatting and having fun. As a result this place has been called by most people as "place of entertainment". Coffee houses have been named as "the schools of wisdom" and "public universities" because of its popularity and attractive.

Recognizing of the Western of the coffeehouses has been through Westerner travellers who visit the entire world. There have been exaggerated expressions of Westerner travellers about coffeehouses they see as in any subject. This narrative style engendered the Western man to look at geography as "utopia". Before too much time on hiatus, the drink and place where is "gathered around" began to be well-known and widespread in the West. As well as culture, arts, education in a way that the dominant elements.

In terms of fulfilling the functions, in coffeehouses many different activities were performed. The art is performed in some coffee houses; it is dealt with literature in others. In addition, the commerce connection is made in some coffeehouses, the theatre is played and the instruments being played in others, the religious books are read in others. Even in some of them cannabis are somked. Sometimes in some of them the prostitution deal is done, or some is just to chat, and in some other coffeehouses there are just bickered. Therefore, coffeehouses, in fact, are the concrete arenas where which the positive and negative social activity attitudes are performed.

The city of Erbil is one of the oldest cities in the world, so it has a rich history. Historian, writers, and researchers always they do not refer to the history of this city in their work (Qader, 2013, p. 271). Erbil is a large city in the north of the Iraqi and south of Kurdistan. Erbil is regarded as the metropolitan of Kurdistan and the tourism city of Iraq (Kurda M. , 2016).

The construction of the city of Erbil came back to the year 3200 BC, when the Sumerians found calligraphy writing in Erbil. Sumerians named the city of Erbil (Örbl). (Eg) the meaning of the word comes from the city in the country, (bL) Only in $6000 \mathrm{BC}$ the Kurdish nation was the owner of this city (hawlergov.org). Once the victims arrived, they changed the name of this city according to their own time. These names have another meaning (Öur, beil, Erbaillo), which means four names (Alhbube, 2013, p. 140). 


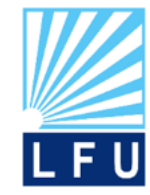

\section{QALAAI ZANIST SCIENTIFIC JOURNAL \\ A Scientific Quarterly Refereed Journal Issued by Lebanese French University - Erbil, Kurdistan, Iraq \\ Vol. ( 3 ), Issue ( 4 ), Fall 2018 \\ ISSN 2518-6566 (Online) - ISSN 2518-6558 (Print)}

Generally, young people and middle-aged people are café customers. A very small number of elderly people are seen in cafes, women also viste it but less than the men. Usually cafes reflect themselves in two ways. In order to play the first shape game, a table and four chairs are set up the second figure is that four hooks are arranged around a table to make a hookah, fruit juice, and two seats stand opposite each other and stand in the centre of a desk. In all the streets of the city of Erbil there are cafes and tea houses, especially in the modest streets.

As winter nights are long, people will meet in the coffee house. Every coffee house has its own story, and the story has a special reverence. Generally, in this coffee house people talk about religion, politics and love. (Abdullah Khayal) is coffee house where the stories are narrated under Arbil castle (Abdulxafar, 1988, p. 157). Erbil is an ancient city, with a rich history of civilization.

\section{Erbil Coffee shops}

Erbil is an old city rich with its culture and it has a lot of coffee shops which some of them will be mentioned.

Kardaran coffee shop is located at the end of the main street which is in a big bazaar in Erbil. It is established in 1960. In the past, many of those who came to the coffee shop owed money, many poor people would pay their money at the end of the month because they did not have the money. For this reason, in 1960 this coffee was named as Kardaran Coffee House, which mea debtor's Coffee (Hakem, 2014).

Workers' Coffee Shop is another Coffee shop which is visited by craftsmen and workers. Usually, It is a place the workers can meet each other and anyone if needs worker or craftsmen can find them easily, in this Coffee to make deals with them (Bexally, 1997).

Quiet is the most unpleasant coffee house in Erbil. Its customers are deaf and dumb, only the sound of the games played, the customers' voices cannot be heard, they speak with by their own methods; only the coffee shop understands them (Rwdaw, 2016).

Iskan Street is an important night bazaar in Erbil. It is one of Arbil's most populous markets. It is open for 24 hours (bot.gov.krd, 2015). Who is going to there 


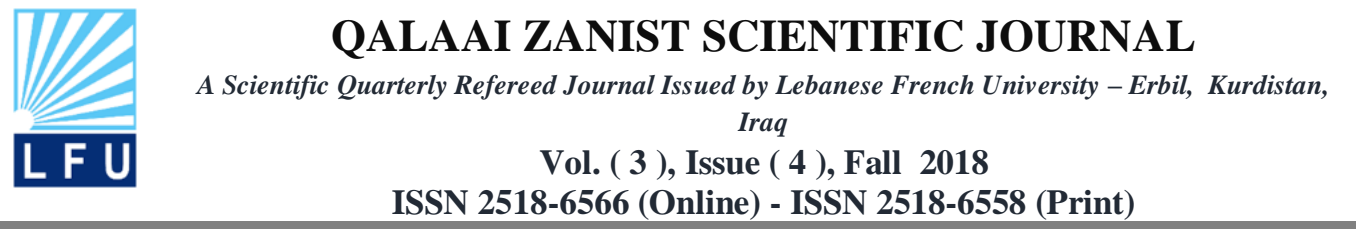

will be asked which coffee house you go!!! During the football matches, it is too crowded. Most of the time this street is closed; cars can not be driven there. So the walking is only a way to enter this street. People come early to book a place, especially if the match is between two great clubs. (Ahmed, 2015).

In the morning, all the restaurants, hammams and coffee shops open in Erbil for preparing breakfast. It's not just for the workers, but for all people. Many kinds of foods and drinks are served, for example (soup, lentil soup, chickpea soup, mackerel, egg, cheese, yoghurt, tea, coffee) (youtube.com, 2013).

\section{The Spread of Coffee}

Human beings have known coffee from a long time ago. At the beginning, coffee has been discovered by the Arabs, it was called Shazili which is an Arabian name. Coffee was spread across the east and coffee plants were sent by ships in Yemen ports to Cairo, which became the most important destination, and coffee shops has become a part of the people's lives across Egypt (Yildiz M. C., 2010, p. 1364).

Recently, there have been a lot of arguments about whether coffee is halal or haram, the fatwa was issued by the Al-Azhar in 1532/1533 and the coffee was prohibited. But this fatwa had not powerful influence because it was a big difference between coffee and drinking alcohol. There was not any change in human behaviour after drinking coffee for example unable to control their behaviour, speech (Hattox, 1996, pp. 33-34).

Nowadays, coffee has spread across the world in different forms and taste and even in different size of cups, plates, jugs, and spoons, etc., there became coffee shops selling coffee drinks, coffee, baked goods, grained coffee, etc. And those coffeehouses became a place where people can sit and chat and a part of their day to day activity.

\section{The Spread of Coffeehouses}

The coffee house has spread all over the world. In each country, they are named differently with the same meaning, for example in Turkey they are called (Kahvehane), in Erbil, they are called (Kawa Khana) (Yıldız M. C., 2010, p. 1365). 


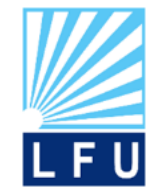

\section{QALAAI ZANIST SCIENTIFIC JOURNAL \\ A Scientific Quarterly Refereed Journal Issued by Lebanese French University - Erbil, Kurdistan, Iraq \\ Vol. ( 3 ), Issue ( 4 ), Fall 2018 \\ ISSN 2518-6566 (Online) - ISSN 2518-6558 (Print)}

Firstly, the coffeehouses spread in Mecca, their first customers were visitors of mosques, sellers, travellers and hajjis. After a while, the coffeehouse was opened in different Arabian city. Coffeehouse is frequently visited by many types of people, and they also became a place where some meetings are held, a spot for a study group, or just a place to sit, drink your favorite beverage and chat (Yıldız M. C., 2010, p. 1364)

Coffee has even made it to the inside of people houses with its own appliances that made it even easier for people to enjoy it in the comforts of their own environment.

The coffeehouse has developed in very important way and changed as everything in our lives. This change has become its name and form. Nowadays are called "Café" this name came from the west.

Very few of people go to cafés alone, they often are accompanied by their friends or relatives (Y1ld1z C. , 1996). Therefore, it is a common place for students, friends and relatives to talk and chat (Karababa. Ger, 2010, p. 7). The aim of going to this place is mostly to meet with colleagues, chatting with friends, playing games, drinking, using internet on laptops and smartphones, reading books, magazines and newspapers (Oral, 1997).

\section{Conclusion and discussion}

Coffee house in Erbil is an important part of its culture and it serves a lot of areas, it can be summarized into the following points:

1. Coffeehouse represents a culture for people of Erbil.

2. It is place for gathering people in Erbil.

3. The main reason for opening coffee shops is to drink coffee, while it has become an important place for talking and discussing problems.

4. It is a great place for playing games and gathering to discuss a special subject.

5. Coffee shops improve social relation through gathering and talking.

6. It is a place for gathering all people from differnt generation, therefore, it makes the realation among them strong. 


\section{QALAAI ZANIST SCIENTIFIC JOURNAL}

A Scientific Quarterly Refereed Journal Issued by Lebanese French University - Erbil, Kurdistan, Iraq

LF U

Vol. ( 3 ), Issue ( 4 ), Fall 2018

ISSN 2518-6566 (Online) - ISSN 2518-6558 (Print)

\section{References}

Abdulxafar, M. $(1988,1)$. Folklor Erbil AU Turatheha. Karwan, pp. 149-159.

Ahmed, N. (2015). Şaqame Eskan Hawadaranı Klaseko Kokrdawa. https://www.youtube.com/watch?v=0yUgKPM2QnY. Erbil: Kurdistan24.

ALEV, E. (2014). ÂŞIK KAHVEHÂNELERINDEN SOSYAL PAYLAŞIM SITELERINE ÂŞIKLIK GELENEĞi. ANKARA: GAZI ÜNIVERSITESI.

Alhbube, s. m. (2013). Makana Erbilım AL madenat And Mulek ALdaulat Ashurea. Mejue Hawler u Rolı Şarstaneate (p. 139). Erbil: Salahdin Universtıy.

Bexally, M. Q. (1997). Hwelerm wa Dewau -- Bestwa. Erbıl: Roşanbery.

Bilge, E. (2010). EVLIYA ÇELEBI'DEN HAREKETLE KAHVEHANELERDEN CAFELERE DÖNÜŞÜM. Ankara.

bot.gov.krd. (2015). http://bot.gov.krd. Retrieved 5 20, 2016, from http://bot.gov.krd/kurdish/erbil-province-erbil/shopping.

Hakem, s. (2014, 11 14). www.youtube.com. Retrieved 2 5, 2016, from https://www.youtube.com/watch?v=qrWIU2qabf8.

Hattox, R. (1996). Kahve ve Kahvehaneler, Bir Toplumsal Gçeceğin Yakındoğudaki Kökenleri, Tarih Vakfı Yurt Yayınları. İstanbul.

Karababa. Ger. (2010). Early Modern Ottoman Coffeehouse Culture and the Formation of the Consumer Subject. Copyright Journal of Consumer Research, 1-41.

Kırlı, C. (1999-2000). Kahvehaneler ve Hafiyeler: 19. Yüzyıl Ortalarında Osmanlı'da Sosyal Kontrol. Toplum ve Bilim, 58-79.

Kurda, M. S. (2009). Çayxana Dernakane Hawler. linsklubedia Hawler, s. 2470-2474.

Lim, M. (2012). Clicks, Cabs, and Coffee Houses: Social Media and Oppositional Movements in Egypt 2004-2011. Journal of Communication, 62(0021-9916), 231-248.

Oral, T. (1997). A CONTEMPORARY TURKISH COFFEEHOUSE DESIGN BASED ON HISTORIC TRADITIONS. Blacksburg. 


\section{QALAAI ZANIST SCIENTIFIC JOURNAL}

A Scientific Quarterly Refereed Journal Issued by Lebanese French University - Erbil, Kurdistan, Iraq

LF U

Vol. ( 3 ), Issue ( 4 ), Fall 2018

ISSN 2518-6566 (Online) - ISSN 2518-6558 (Print)

Özdemir, S. M. (2010). Toplumsal Değişme ve Küreselleşme Bağlamında

ÇözümlemeEğitim ve Eğitim Programları: Kavramsal... Ahi Evran Üniversitesi Eğitim Fakültesi Dergisi, 85-110.

Qader, c. (2013). Erbil fe salnamat usmanea. Journal of the kurdish Academy, 271- 298.

Rwdaw (2016). [Motion Picture].

Yıldız, C. (1996). Kahvehanelerin Sosyal Hayattaki Yeri. Fırat Üniversitesi Sosyal Bilimeler, 2, Cilt:8, Sayı:2.

Yıldız, M. C. (2010). Coffeehouses as an informal education institution and coffeehouses of Egypt. Procedia Social and Behavioral Sciences, 9, 1362-1367.

youtube.com. (2013, 3 11). youtube.com. Retrieved 5 10, 2016, from https://www.youtube.com/watch?v=FK7gfUdWKgU. 